\title{
First record of Aylacostoma francana (Ihering, 1909) (Gastropoda, Thiaridae) in Minas Gerais state, Brazil
}

\author{
Lucas Rezende Penido Paschoal ${ }^{1 *}$ \\ Douglas de Pádua Andrade ${ }^{1}$ \\ Daniel Caracanhas Cavallari ${ }^{2}$ \\ ${ }^{1}$ Laboratório de Hidrobiologia, Departamento de Ciências Biológicas \\ Fundação de Ensino Superior de Passos/Universidade do Estado de Minas Gerais \\ CEP 37900-106, Passos - MG, Brasil \\ ${ }^{2}$ Museu de Zoologia da Universidade de São Paulo, Universidade de São Paulo, São Paulo - SP, Brasil \\ * Autor para correspondência \\ lucasrezende20@gmail.com
}

Submetido em 09/10/2012

Aceito para publicação em 05/03/2013

\section{Resumo}

Primeiro registro de Aylacostoma francana (Ihering, 1909) (Gastropoda, Thiaridae) no estado de Minas Gerais. Aylacostoma francana (Ihering, 1909) é uma espécie de caramujo de água doce pertencente à família Thiaridae, com distribuição geográfica atualmente restrita ao Estado de São Paulo. O presente trabalho visa reportar a ocorrência da espécie no Estado de Minas Gerais. Os possíveis meios de introdução e algumas características dessa espécie e das novas áreas de ocorrência são discutidos no presente trabalho.

Palavras chave: Aylacostoma francana; Introdução acidental; Molusco nativo

\section{Abstract}

Aylacostoma francana (Ihering, 1909) is a species of freshwater snail belonging to the family Thiaridae with distribution currently restricted to São Paulo state, southeastern Brazil. This paper aims to report the first record of the species in Minas Gerais state. Possible means of introduction, as well as some characteristics of this species and new areas of occurrence, are discussed herein.

Key words: Accidental introduction; Aylacostoma francana; Native mollusk

Benthic macroinvertebrates constitute a very diverse group of organisms capable of inhabiting many types of substrates and aquatic ecosystems and are represented by a large number of phyla (MERRITT; CUMMINS, 1996). Among the phyla comprising the lentic environment macrofauna, the Mollusca Linnaeus,
1758 are a notorious group. Their representatives usually have high densities and consequently large biomass (MANSUR et al., 2003). They are often used as biomonitors, for they are sensitive to pollution and eutrophication and are able to accumulate various pollutants in aquatic environments (DARRIGRAN, 
1999). It should be noted that they have an important role in the food chain and in the cycling of organic matter in aquatic ecosystems (VAUGHN, 2010).

Among the Mollusca, the limnic gastropods in the family Thiaridae Gill, 1871 stand out in the current Pan-American scenario, mainly due to the introduction of the invasive Melanoides tuberculatus (Müller, 1774) and the environmental changes stemming from it (see FERNANDEZ et al., 2003; PAULA-ANDRADE et al., 2012 for details). Moreover, this family includes a genus native to Central and South America, Aylacostoma Spix, 1827, which is widely distributed in freshwater aquatic environments. Its occurrence is recorded from Cuba to Uruguay, with 32 known species (SIMONE, 2006). Species in this genus currently recorded in Brazil include Aylacostoma francana (Ihering, 1909), among others. So far, its occurrence has been restricted to São Paulo state (SIMONE, 2006), but it has now expanded to Minas Gerais state, as shown here.

\section{Sampling area}

The Hydroelectric Power Station (HPS) Marechal Mascarenhas de Morais is located near the municipality of Ibiraci (Minas Gerais), between HPS Furnas (upstream) and HPS Luiz Carlos Barreto de Carvalho (downstream) (Figure 1). The reservoir has flooded an area of $250 \mathrm{~km}^{2}$ and is situated in the middle Rio Grande watershed, in a region with a high population density, with the main economic activity concentrated in the primary sector (i.e. livestock and sugar cane, orange and coffee crops). It is important for the region as a water reserve and power source, as well as a place of leisure and source of income for many fishing families. Moreover, it has great wildlife diversity, directly and indirectly (PASCHOAL et al., 2013).

This species was found on the banks of a portion of the Rio Grande during benthic macroinvertebrate sampling on August 2012 at two sampling points - P1 and P2 - situated in HPS Mascarenhas de Morais, in

FIGURE 1: Aylacostoma francana. Distribution and sampling sites.

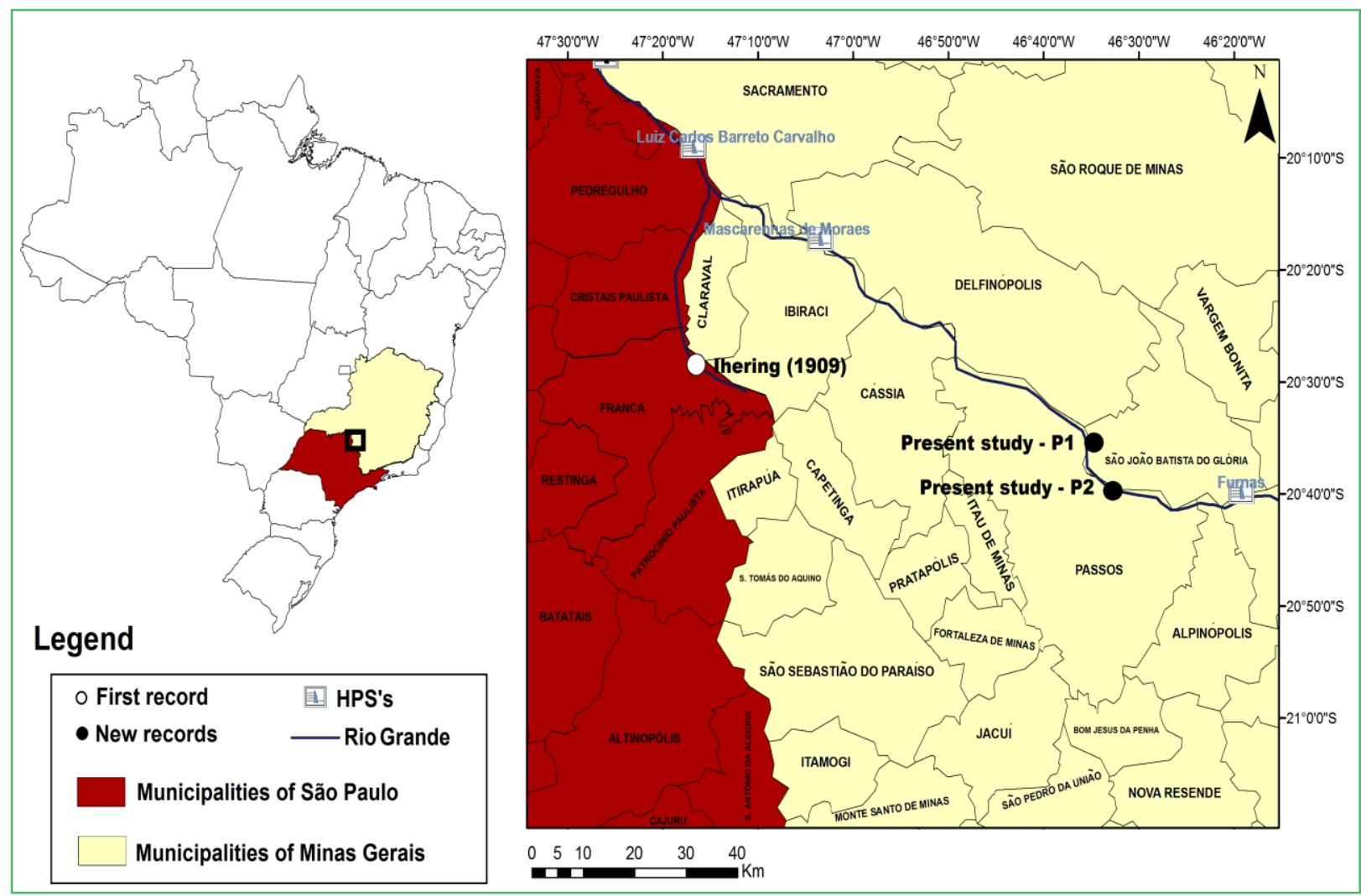


the municipality of São João Batista do Glória, Minas Gerais state (Figure 1).

The P1 sampling point - situated on the right margin of the Rio Grande - is characterized by extensive water column fluctuation, prevalence of siltclay sediment, presence of gravel and boulders along the margins, a predominance of Brachiaria sp. (Trin.) Griseb. close to the margin, and banks of Eichornia azurea (Kunth) along the riverbed. In this area there is intensive farming of Oreochromis niloticus (Linnaeus, 1758) (Nile tilapia) in net cages. The P2 sampling point - located on the left margin of the Rio Grande is characterized by the prevalence of sandy sediment, altered natural depth of the bed and exposure to large anthropogenic influence (e.g., barrages and companies). Extraction and transportation of sand is common in this area, which has possibly caused environmental changes (ANDRADE; PASCHOAL, personal observations). $A$. francana was recorded only at these points, even after extensive surveys in other areas of southeastern Minas Gerais.

\section{Collection and identification}

Individuals were obtained using two collection methods: I) in shallow environments - ranging from 0 to $150 \mathrm{~cm}$, where the specimens were collected by manual scavenging by two collectors, during an hour period in the margins and/or in aquatic environments and II) in

FIGURE 2: Aylacostoma francana. Phenotypic variation. Notice the sharper or rounded outlines, and different periostracum colorations. Bars: $5 \mathrm{~mm}$.

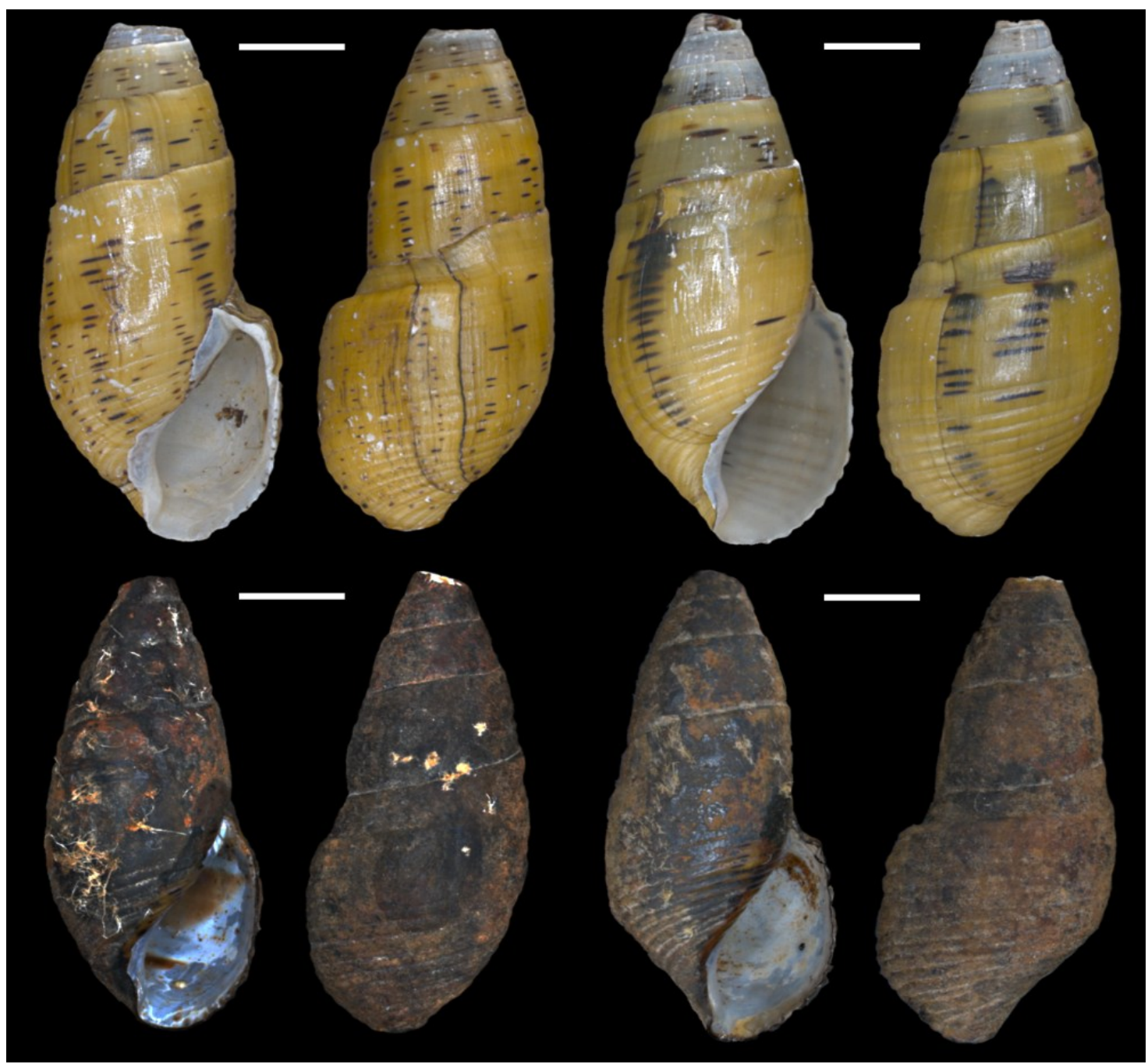


environments with greater depths, more than $150 \mathrm{~cm}$, where the collectors employed a modified Petersen-type sampler $\left(353 \mathrm{~cm}^{2}\right)$ to obtain bottom sediment samples.

Afterwards, the resulting materials were placed in trays for sorting and organisms found were fixed in $70 \%$ ethanol for later identification under stereomicroscope. Species were identified according to Simone (2006).

We observed that $A$. francana $(\mathrm{N}=242)$ showed great phenotypic plasticity (Figure 2 ) and was found at depths ranging from $30 \mathrm{~cm}$ to $6 \mathrm{~m}$. Its mean population density in the region was close to $200 \mathrm{ind} / \mathrm{m}^{2}$. Other gastropod species were found living in the same area, mainly M. tuberculatus and Pomacea lineata (Spix, 1827) along with bivalves, mainly Corbicula fluminea (Müller, 1774). Field observations indicated that $A$. francana showed the highest density among mollusk species in the area.

\section{Possible means of introduction}

The occurrence of $A$. francana in the area may be due to the fish farming net cages and the accidental transport of sand containing adults and/or propagules. These incidences have been often observed in this region, coupled with the fact that no Aylacostoma representatives had been collected before in the same area during the past decade (PASCHOAL, unpublished data).

According to Agostinho et al. (2007) and AzevedoSantos et al. (2011) aquaculture net cages may be the most important vector for species introductions in Brazilian aquatic environments. These authors suggest that this is due to the rapid growth of this kind of activity in several basins, and the lack of guidance for producers allied with governmental incentives. During field work, we noticed the presence of adult individuals and egg masses of gastropods in the fishing net cages, which is critical evidence of this invasion (ANDRADE; PASCHOAL, personal observations).

Counts (1986) reviewed of the mechanisms of dispersal of the invasive bivalve $C$. fluminea and concluded that the main means of dispersal are the release of bait and specimens used in aquaria into water bodies and accidental transport of sand and gravel containing living organism to areas near aquatic environments. Belz (2006) studied the dispersal mechanisms for Limnoperna fortunei (Dunker, 1857), another invasive bivalve, through a risk analysis in reservoirs in Paraná state (southern Brazil), and attributed high introduction risks to fish farming, while considering accidental transport of sand and fishing as low risk. In this paper, we observed that accidental transport of sand can also be an important vector for species introductions.

The new records of $A$. francana are relatively close $(\sim 150 \mathrm{~km})$ to the type locality reported by von Ihering (1909), the municipality of Franca, in São Paulo state (Figure 1). The Minas Gerais - São Paulo axis harbors several busy construction sites along its state highways. It is possible that through this activity, commonplace in economically thriving southeastern Brazil, this species may have been accidentally removed from the rivers of São Paulo and brought to the Rio Grande basin, establishing itself over the years.

Voucher specimens collected were deposited in the Museu de Zoologia da Universidade de São Paulo (MZUSP), under codes MZSP 108047, 108048 and 108049.

\section{Acknowledgements}

We thank Dr. Luiz R. L. Simone (MZUSP) for confirming species identifications and biologists Aline C. C. Francez for helping with field work and Thor A. di Sessa for packing, transportation and shipment of the voucher samples to MZUSP.

\section{References}

AgOstinho, A. A., GOMES, L. C.; PELICICE, F. M. Ecologia e manejo de recursos pesqueiros em reservatórios do Brasil. Maringá: Eduem, 2007. 501 p.

AZEVEDO-SANTOS, V. M.; RIGOLIN-SÁ, O.; PELICICE, F. $\mathrm{M}$. Growing, losing or introducing? Cage aquaculture as a vector for the introduction of non-native fish in Furnas Reservoir, Minas Gerais, Brazil, Neotropical Ichthyology, Porto Alegre, v. 9, n. 4, p. 915-919, 2011.

BELZ, C. E. Análise de risco de bioinvasão por Limnoperna fortunei (DUNKER, 1857): um modelo para a bacia do rio Iguaçu, Paraná. 2006. 102 f. Tese (Doutorado em Zoologia) - Universidade Federal do Paraná, Curitiba. 2006. 
COUNTS, C. L. The zoogeography and history of the invasion of the United States by Corbicula fluminea (Bivalvia: Corbiculidae). American Malacological Bulletin, Washington, v. 2, p. 7-39, 1986.

DARRIGRAN, G. Longitudinal distribution of molluscan communities in the Río de la Plata estuary as indicators of environmental conditions. Malacological Review supl. Freshwater Mollusca, Michigan, v. 8, p. 1-12, 1999.

FERNANDEZ, M. A., THIENGO, S. C.; SIMONE, L. R. L. Distribution of the introduced freshwater snail Melanoides tuberculatus (Gastropoda: Thiaridae) in Brazil. The Nautilus, Sanibel, v. 117, n. 3, p. 78-82, 2003.

MANSUR, M. C. D.; DOS SANTOS, C. P.; DARRIGAN, G.; HEYDRICH, I.; CALLIL, C. T.; CARDOSO, F. R. Primeiros dados quali-quantitativos do mexilhão-dourado, Limnoperna fortunei (Dunker), no Delta do Jacuí, no Lago Guaíba e na Laguna dos Patos, Rio Grande do Sul, Brasil e alguns aspectos de sua invasão no novo ambiente. Revista Brasileira de Zoologia, Curitiba, v. 20, p. 75-84, 2003.

MERRITT, R. W.; CUMMINS, K. W. An introduction to the aquatic insects of North America. Dubuque: Kendal/Hunt Publication Company, 1996. 862 p.
PASCHOAL, L. R. P.; RIGOLIN-SÁ. O.; FERREIRA, M. N. L. Análise da qualidade da água utilizando o índice do estado trófico (IET) e o índice da qualidade da água (IQA). In: RIGOLIN-SÁ, O. (Org.). Bacia hidrográfica: estudos do Rio Grande no Sudoeste de Minas Gerais - Brasil. Passos: Edifesp, 2013. p. 83-93.

PAULA-ANDRADE, C.; PINTO, H. A.; COSCARELLI, D.; VIDIGAL, T. H. D. A.; MELO, A. L. The natural infection of Melanoides tuberculata (Müller, 1774) (Mollusca: Gastropoda) by Centrocestus formosanus (Nishigori, 1924) (Platyhelminthes: Trematoda) in Paranoá lake, Brasília, Brazil. Brazilian Journal of Biology, São Carlos, v. 72, n. 2, p. 419-420, 2012.

SIMONE, L. R. L. Land and freshwater molluses of Brazil: an illustrated inventory on the Brazilian malacofauna, including neighbour regions of the South America, respect to the terrestrial and freshwater ecosystems. São Paulo: FAPESP, 2006. 390 p.

VAUGHN, C. Biodiversity losses and ecosystem function in freshwaters: emerging conclusions and research directions. BioScience, California, v. 60, p. 25-35, 2010.

VON IHERING, H. Lés Mélaniides Américans. Journal of Conchyliologie, Paris, v. 57, p. 289-316, 1909. 